\title{
アクティブ制振ユニットによる 柔軟構造物の適応スカイフックー外乱相殺併合制御*
}

\author{
星野洋平*1, 片山 恭平*2, 小林 幸徳*3, 江丸 貴紀*1, 中西 洋介*4

\section{Sky-Hook with Adaptive Disturbance Cancellation Control for Flexible Structures by Active Vibration Control Unit} \\ Yohei HOSHINO*1, Kyohei KATAYAMA, Yukinori KOBAYASHI \\ Takanori EMARU and Yosuke NAKANISHI \\ ${ }^{* 1}$ Faculty of Engineering, Hokkaido University, N13W8, Kita-ku, Sapporo, Hokkaido, 060-8628 Japan
}

This study presents Active Wheel Damper (AWD) unit which can be fixed on the flexible structures such as cantilever beam with ease. The AWD uses a gyro sensor to measure the absolute angular velocity due to the vibration of deflection of the structure directly, and can construct sky-hook control with no difficulty by direct feedback of the angular velocity. In this study, Sky-hook With Adaptive Disturbance Cancellation (SWADC) control, which is constructed as a combined control system of sky-hook control and adaptive disturbance cancellation control, is also proposed to enhance the performance of vibration suppression of AWD unit. Adaptive algorithm, which can estimate the frequency of the vibration of the structure in real-time, is derived based on adaptive notch filter algorithm, and estimated frequency is used for the model of disturbance observer which estimates harmonic disturbance. Performance of vibration suppression of the AWD is shown by simulation and experiment in this study.

Key Words : Sky-Hook Control, Active Mass Damper, Fly-Wheel, Adaptive Disturbance Cancellation

\section{1. は じ め に}

アクティブ制振装置の代表例として，アクティブマスダンパ（AMD:Active Mass Damper）がある. AMD は，セ ンサで振動系の状態を観測し，慣性質量をアクチュエータの発生力によって加速することで，加速のための作用に 対する反作用を利用し振動系を制振する。直動型の AMD を用いて大型柔軟構造物に大きな制御力を与えるため には，大きな質量を有する慣性質量と並進運動のための充分なストロークが必要となる.片持ちはり状の細長い 柔軟構造物のたわみ振動の除振のために AMD を適用する場合, 慣性質量を大きくすることで重力によるたわみ が顕著になることや, 確保できる AMD のストロークが限られるため, 充分な制振力を発生させることが難しい. そこで，著者らは片持ちはりの柔軟変形に伴う振動抑制のために，図 1 に示すようなモータ, フライホイール, センサ，マイコンから構成される回転型のアクティブ制振ユニット（AWD:Active Wheel Damper）を提案し，こ の制振ユニットを柔軟な片持ちはり状構造である農業用農薬散布機（ブームスプレーヤ）の作業アーム（ブーム） に適用して，ブームの振動抑制に有効であることをシミュレーションと実験により示した(1). AWD ユニットは, 慣性質量の役目を果たすフライホイールをモータによって発生させるトルク $-M$ て加速し, 同時に発生する反ト ルク $M$ を利用して，制御対象を制振する。回転型とすることで，大きな制振力が必要な場合でも，高慣性（慣性 モーメント J）の慣性質量（フライホイール）を軽量で実現できるだけでなく，慣性質量の運動に要するストロー クを無限に確保できるメリットがあり，農業用ブームスプレーヤのような細長い柔軟構造物に対しても搭載する

\footnotetext{
* 原稿受付 2011 年 10 月 19 日

${ }^{* 1}$ 正員, 北海道大学大学院工学研究院（ $\bar{T} 060-8628$ 北海道札幌市北区北 13 条西 8 丁目）

${ }^{* 2}$ 北海道大学大学院工学院

*3 正員, フェロー, 北海道大学大学院工学研究院

${ }^{* 4}$ 正員, 北海道立総合研究機構 工業試験場（广060-0819 北海道札幌市北区北 19 条西 11 丁目）

E-mail: hoshinoy@eng.hokudai.ac.jp
} 


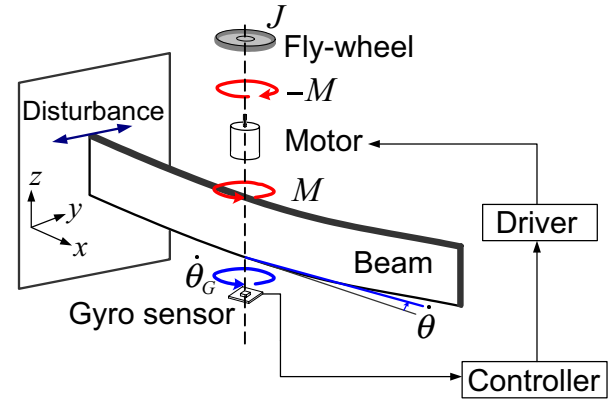

Fig. 1 Active Wheel Damper (AWD)

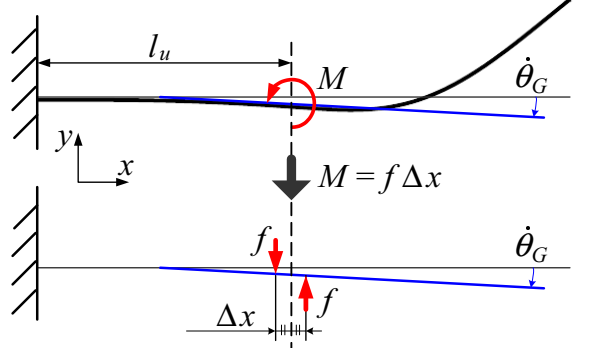

Fig. 2 Euler-Bernoulli beam and input moment

ことが可能である．また，ジャイロセンサを用いることで，容易に絶対角速度を計測することが可能となり，特に スカイフック制御の構成が容易となる。 さらに, 慣性質量とアクチュエータならびにセンサを 1 つのモジュール に集約することができ，容易に着脱可能な制振装置を構成できる点でも有用である.

この研究では, 片持ちはりの振動が外乱による強制振動の結果として生じるものと考え, 適応ノッチフィルタア ルゴリズム ${ }^{(2)}$ を用いて外乱の振動数をリアルタイムに推定し，AWDにスカイフック制御を適用した場合 ${ }^{(1)}$ に対

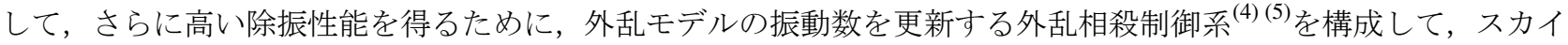
フック制御系との併合制御系を構築することにより AWD ユニットの制振性能の向上を図る．片持ちはりにユニッ トを搭載した場合の実験ならびにシミュレーションにより制振性能を確認する.

\section{2. モ デリン グ}

密度 $\rho$, 長さ $L$, 断面積 $A$, 曲げ岡性 $E I$ の片持ちはりに対して, はりの軸上の位置 $x$ に対して単位長さあたり の分布力 $F(x, t)$ が働くとき，オイラー・ベルヌーイはりの理論によれば，はりの運動方程式は,

$$
\rho A \ddot{y}(x, t)+E I y^{\prime \prime \prime \prime}(x, t)=F(x, t)
$$

となる.ここで， $\dot{y}(x, t)$ ならびに $y^{\prime}(x, t)$ はそれぞれ時刻 $t$ と位置 $x$ による一階の偏微分を表すものとする．はり のたわみ $y(x, t)$ を, 片持ちはりの境界条件からモード解析によって求めた $j$ 次の固有振動モード関数 $\phi_{j}(x)$ と $j$ 次 モードの時間関数 $q_{j}(t)$ を用いてモード展開すると,

$$
y(x, t)=\sum_{j=1}^{\infty} \phi_{j}(x) q_{j}(t)
$$

となる.これを式 (1) に代入し, 両辺に $\phi_{i}(x)$ を乗じてはりの全長にわたって積分すると, 固有振動モードの直交 性により第 $i$ 次振動モードの運動方程式

$$
\ddot{q}_{i}(t)+\omega_{i}^{2} q_{i}(t)=\frac{\int_{0}^{L} F(x, t) \phi_{i}(x) d x}{\rho A \int_{0}^{L} \phi_{i}^{2}(x) d x}
$$

が得られる. ただし， $\omega_{i}$ は $i$ 次の円固有振動数である. 図 1 のように, モータがフライホイールに与えるトルク - $M$ に対する反トルク $M$ を利用し，はりにモーメント入力 $M$ を与える。モーメント $M$ を図 2 のように一組の偶 力 $f$ で表すと,

$$
M=f \Delta x
$$

となる. ただし, $\Delta x$ は偶力の腕であり, 微小長さとする. 制振ユニット搭載位置 $x=l_{u}$ を $\Delta x$ の中点とすると, 偶 力は $x=\left(l_{u}+\Delta x / 2\right)$ の一点に働く集中力 $f$ と $x=\left(l_{u}-\Delta x / 2\right)$ の一点に働く集中力 $-f$ に分解できる. 制振ユニッ トがはりに与える力 $F(x, t)$ をディラックのデルタ関数 $\delta(x)$ を用いて表すと,

$$
F(x, t)=f(t) \delta\left(x-\left(l_{u}+\frac{\Delta x}{2}\right)\right)-f(t) \delta\left(x-\left(l_{u}-\frac{\Delta x}{2}\right)\right)
$$

となる.さらに, 式 (5)の両辺に $\phi_{i}(x)$ をかけ, はりの全長にわたって積分すると, ディラックのデルタ関数の性 質から,

$$
\int_{0}^{L} F(x) \phi_{i}(x) d x=f(t)\left[\phi_{i}\left(l_{u}+\frac{\Delta x}{2}\right)-\phi_{i}\left(l_{u}-\frac{\Delta x}{2}\right)\right]=M(t) \cdot \frac{\phi_{i}\left(l_{u}+\frac{\Delta x}{2}\right)-\phi_{i}\left(l_{u}-\frac{\Delta x}{2}\right)}{\Delta x}
$$


となる．距離 $\Delta x$ は微小なので $\Delta x \rightarrow 0$ の極限を取れば，式(6) はさらに計算を進めることができ,

$$
\int_{0}^{L} F(x) \phi_{i}(x) d x=\left.M(t) \frac{d \phi_{i}}{d x}\right|_{x=l_{u}}=M(t) \phi_{i}^{\prime}\left(l_{u}\right)
$$

となる.このモーメント $M(t)$ は，モータからの入カトルク $\tau(t)$ であるので，式 (3) は，

$$
\ddot{q}_{i}(t)+\omega_{i}^{2} q_{i}(t)=\frac{\tau(t) \phi_{i}^{\prime}\left(l_{u}\right)}{\rho A \int_{0}^{L} \phi_{i}^{2}(x) d x}
$$

と表せる. はりの位置 $l_{u}$ における第 $i$ 次振動によるたわみ角 $\theta_{i}(t)$ の運動方程式は, 式 $(8)$ の両辺に $\phi_{i}^{\prime}\left(l_{u}\right)$ をかけ,

$$
J_{i} \ddot{\theta}_{i}(t)+K_{i} \theta_{i}(t)=\tau(t), \quad J_{i}=\frac{\rho A \int_{0}^{L} \phi_{i}^{2}(x) d x}{\phi_{i}^{\prime 2}\left(l_{u}\right)}, K_{i}=\omega_{i}^{2} \cdot \frac{\rho A \int_{0}^{L} \phi_{i}^{2}(x) d x}{\phi_{i}^{\prime 2}\left(l_{u}\right)}
$$

と表される. はりの状態は，ジャイロセンサによって絶対角速度 $\dot{\theta}_{G}$ を計測することで得られる. はりの位置 $l_{u} に$ 取り付けたジャイロセンサによって計測される絶対角速度 $\dot{\theta}_{G}$ は,

$$
\dot{\theta}_{G}=\dot{y}^{\prime}\left(l_{u}, t\right)=\sum_{j=1}^{\infty} \phi_{j}^{\prime}\left(l_{u}\right) \dot{q}_{j}(t)
$$

となる。

\section{3. 制御 系の 設 計}

\section{$3 \cdot 1$ 適応ノッチフィルタ}

$z$ 変換で表現された IIR 型 2 次ノッチフィルタ

$$
H(z)=\frac{\left(\rho_{\mathrm{NF}}^{2}+1\right)+2 a z^{-1}+\left(\rho_{\mathrm{NF}}^{2}+1\right) z^{-2}}{2\left(1+a z^{-1}+\rho_{\mathrm{NF}}^{2} z^{-2}\right)}
$$

のノッチ角周波数 $\omega$ がパラメータ $a$ によって決定されることを利用して，未知の狭帯域信号の周波数とノッチ周 波数 $\omega$ を一致させるようにパラメータ $a$ を更新する適応ノッチフィルタを構成できる ${ }^{(2)(3)}$. ただし， $\rho_{\mathrm{NF}}$ はノッチ フィルタの帯域幅を決定するパラメータである. 式(11)のパラメータ $a$ を第 $k$ サンプル時のパラメータ $a_{k}$ を用い て書き改め，次式のように表現する.

$$
H(z)=\frac{N(z)}{D(z)}=\frac{\left(\rho_{\mathrm{NF}}^{2}+1\right)+2 a_{k} z^{-1}+\left(\rho_{\mathrm{NF}}^{2}+1\right) z^{-2}}{2\left(1+a_{k} z^{-1}+\rho_{\mathrm{NF}}^{2} z^{-2}\right)}
$$

式(12)のノッチフィルターの入力を $u(k)$, 出力を $y(k)$ とし, $1 / D(z)$ に対する出力を $x(k)$ とすると,

$$
y(k)=N(z) x(k), x(k)=\frac{1}{D(z)} u(k)
$$

となる. $N(z) x(k)$ の計算から, 出力 $y(k)$ を $x(k)$ の差分方程式で表現すると,

$$
y(k)=\left(\rho_{\mathrm{NF}}^{2}+1\right) x(k)+2 a_{k} x(k-1)+\left(\rho_{\mathrm{NF}}^{2}+1\right) x(k-2)
$$

を得る，適応フィルタのアルゴリズムは，次の評価関数

$$
E(k)=\sum_{i=0}^{k} \lambda^{k-i} y^{2}(i)
$$

を最小化するように係数を逐次的に更新していく逐次最小 2 乗法で導出される.ただし， $\lambda$ は忘却係数である。こ こで,

$$
A(k)=x(k-1), \quad B(k)=x(k)+x(k-2)
$$

と定義すると，式(14) は，

$$
y(k)=\left(\rho_{\mathrm{NF}}^{2}+1\right) B(k)+2 a_{k} A(k)
$$




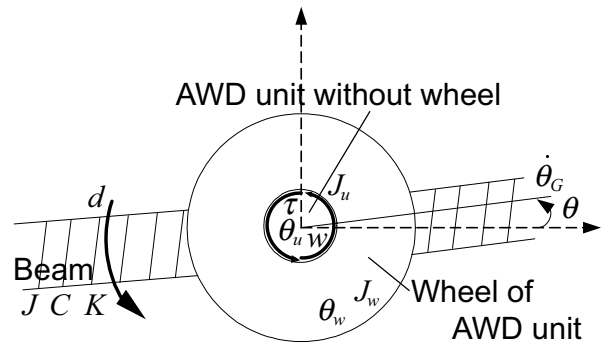

Fig. 3 Dynamics model of AWD and cantilevered beam

となり，さらに式(15)に代入すると，

$$
E(k)=\sum_{i=0}^{k} \lambda^{k-i}\left[\left(\rho_{\mathrm{NF}}^{2}+1\right)^{2} B^{2}(i)+4 a_{k}\left(\rho_{\mathrm{NF}}^{2}+1\right) A(i) B(i)+4 a_{k}^{2} A^{2}(i)\right]
$$

が得られる. 評価関数 $E(k)$ を最小にする $a_{k}$ は,

$$
\frac{\partial E(k)}{\partial a_{k}}=\sum_{i=0}^{k} \lambda^{k-i}\left[4\left(\rho_{\mathrm{NF}}^{2}+1\right) A(i) B(i)+8 a_{k} A^{2}(i)\right]=0
$$

を満たす.したがって, 適応フィルタの係数は,

$$
a_{k}=-\frac{\left(\rho_{\mathrm{NF}}^{2}+1\right)}{2} \cdot \frac{\sum_{i=0}^{k} \lambda^{k-i} A(i) B(i)}{\sum_{i=0}^{k} \lambda^{k-i} A^{2}(i)}
$$

となる.ここで，新たに $\Phi(k), \eta(k)$ を

$$
\begin{gathered}
\Phi(k)=\lambda \Phi(k-1)+A^{2}(k) \\
\eta(k)=\lambda \eta(k-1)+A(k) B(k)
\end{gathered}
$$

と定義すると, 適応フィルタの係数 $a_{k}$ は,

$$
a_{k}=-\frac{\left(\rho_{\mathrm{NF}}^{2}+1\right)}{2} \cdot \frac{\eta(k)}{\Phi(k)}
$$

と表現できる. サンプリング周期を $T$ とすると，ノッチ周波数 $\omega_{k}$ と $a_{k}$ の関係から, 構造物の角振動数は,

$$
\omega_{k}=\frac{1}{T} \cos ^{-1}\left(\frac{-a_{k}}{\rho_{\mathrm{NF}}^{2}+1}\right)
$$

により逐次推定することができる.この研究では, 角振動数 $\omega_{k}$ をバンドパスフィルタ $(\mathrm{BPF})$ の中心周波数と後述 の外乱相殺制御の外乱モデルの振動数として利用することで, 振動数に適応する制御系を構築する.

\section{$3 \cdot 2$ 制御モデル}

特定の振動モードに着目した場合の片持ちはり, フライホイールを除く AWD ユニットならびにフライホイール に関する運動方程式は，それぞれ次のように表せる.

$$
\begin{gathered}
J \ddot{\theta}+C \dot{\theta}+K \theta=-w+d \\
J_{u} \ddot{\theta}_{u}=w+\tau \\
J_{w} \ddot{\theta}_{w}=-\tau
\end{gathered}
$$

ここで， $J_{u}$ はフライホイールを除いた AWD ユニットの慣性モーメントであり， $J_{w}$ はフライホイールの慣性モー メントを表す. また， $d$ は片持ちはりに入力される外乱である. $w$ はユニットに対する外乱であり，片持ちはりに 取り付けられたユニットがはりの振動によってはりから受ける接触力 (内力) に起因する (図 3). AWD ユニットの 
回転角 $\theta_{u}$ は，片持ちはりへの取り付け位置におけるたわみ角 $\theta$ に等しいため $\theta_{u}=\theta$ であり, AWD ユニットを取 り付けたはりの運動方程式は, 式 (25) と式 (26) の両辺を足し合わせて,

$$
\left(J+J_{u}\right) \ddot{\theta}+C \dot{\theta}+K \theta=\tau+d
$$

である．また $\theta_{w}$ はフライホイールの回転角である.

本研究では, 外乱が突発的な衝撃等に起因する過渡的外乱と持続的外乱の 2 つ特性を有するものと仮定する. 前者にはフィードバック制御系, 後者にはフィードフォワード制御系を適用寸ることで高い除振性能が期待でき る. 本研究では, フィードバック・フィードフォワード併合制御 ${ }^{(4)}(5)$ を適用寸る. 本論文で用いる制御入力は,

$$
\tau=\tau_{f b}+\tau_{f f}
$$

とする. $\tau_{f b}, \tau_{f f}$ はそれぞれ，フィードバック制御入力，フィードフォワード制御入力である.

\section{$3 \cdot 3$ フィードバック制御系 (スカイフック制御)}

フィードバック制御については，全周波数領域で減衰を付加して振幅を減少させることが可能なスカイフック ダンパの特性を有するスカイフック制御を適用する，本研究で開発した制振ユニットでは，制御対象のたわみ振 動による絶対角速度をジャイロセンサで直接計測するため，容易にスカイフック制御系を実現できる．式 (25) か ら (27) のモデルにスカイフック制御を適用し

$$
\tau_{f b}=-K_{s k y} \dot{\theta}
$$

とする. AWD ユニットにより連続時間でのスカイフック制御系を構成した場合, センサとアクチュエータの配置 がほぼ理想的なコロケーションの関係となるため, 高次振動モードについても減衰を付加することとなり安定と なる.

\section{$3 \cdot 4$ フィードフォワード制御系 (外乱相殺制御)}

AWD ユニットの運動のみを考慮して状態方程式を導出する．はじめに外乱のダイナミクスをモデル化する．本 研究では適応ノッチフィルタにより得られる式 (24) の角振動数 $\omega_{k}$ を調和励振力 $w$ の円振動数として用い, 調和 励振力モデルを

$$
\ddot{w}+\omega_{k}^{2} w=0
$$

と表現する．したがって，外乱の状態方程式モデルは

$$
\begin{gathered}
\dot{\boldsymbol{w}}=\boldsymbol{A}_{0} \boldsymbol{w} \\
\boldsymbol{A}_{0}=\left[\begin{array}{cc}
0 & 1 \\
-\omega_{k}^{2} & 0
\end{array}\right], \boldsymbol{w}=\left[\begin{array}{c}
w \\
\dot{w}
\end{array}\right]
\end{gathered}
$$

と表現できる．外乱と AWD ユニットの連成系の状態方程式は，式 (26) と (32) から，

$$
\begin{gathered}
\dot{\boldsymbol{X}}=\boldsymbol{A} \boldsymbol{X}+\boldsymbol{B} \tau \\
\boldsymbol{X}=\left[\begin{array}{c}
\dot{\theta} \\
w \\
\dot{w}
\end{array}\right], \boldsymbol{A}=\left[\begin{array}{ccc}
0 & 1 / J_{u} & 0 \\
0 & 0 & 1 \\
0 & -\omega_{k}^{2} & 0
\end{array}\right], \boldsymbol{B}=\left[\begin{array}{c}
1 / J_{u} \\
0 \\
0
\end{array}\right]
\end{gathered}
$$

と表せる．式(34)のシステムに対して，フィードフォワード制御系を設計するためには，何らかの方法で励振力 $w$ を計測する必要があるが，これを直接計測することはできない。この研究では，外乱 $w$ を推定するために外乱

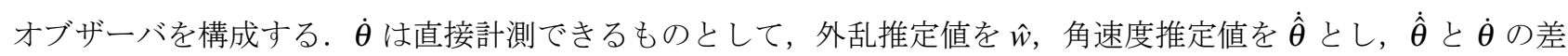
をフィードバックすると，

$$
\dot{\hat{\boldsymbol{X}}}=\boldsymbol{A} \hat{\boldsymbol{X}}+\boldsymbol{B} \tau+\boldsymbol{L}(\dot{\hat{\theta}}-\dot{\theta})
$$




$$
\hat{\boldsymbol{X}}=\left[\begin{array}{ccc}
\dot{\hat{\theta}} & \hat{w} & \dot{\hat{w}}
\end{array}\right]^{T}, \boldsymbol{L}=\left[\begin{array}{lll}
l_{1} & l_{2} & l_{3}
\end{array}\right]^{T}
$$

と表せる.ここで，記号^は推定值を表し，Lは設計パラメータである.また，式 (36) と式 (34) の差をとると

$$
\begin{gathered}
\dot{\boldsymbol{e}}=\boldsymbol{A} \boldsymbol{e}+\boldsymbol{L}(\dot{\hat{\boldsymbol{\theta}}}-\dot{\boldsymbol{\theta}})=\boldsymbol{A}^{\prime} \boldsymbol{e} \\
\boldsymbol{A}^{\prime}=\left[\begin{array}{ccc}
l_{1} & 1 / J_{u} & 0 \\
l_{2} & 0 & 1 \\
l_{3} & -\omega_{k}^{2} & 0
\end{array}\right], \boldsymbol{e}=\left[\begin{array}{c}
\dot{\hat{\theta}}-\dot{\theta} \\
\hat{w}-w \\
\dot{\hat{w}}-\dot{w}
\end{array}\right]
\end{gathered}
$$

となる.この状態変数 $\boldsymbol{e}$ の特性は行列 $\boldsymbol{A}^{\prime}$ の極 $\lambda_{1}, \lambda_{2}, \lambda_{3}$ で決まる. 極配置法では, 極 $\lambda_{1}, \lambda_{2}, \lambda_{3}$ が望办の極と一 致するように設計定数 $\boldsymbol{L}$ を決定する. 外乱励振力は, 式 (36) によって推定することができる. フィードフォワー ド制御入力は，外乱を相殺するように決定すれば良いので， $\alpha$ をゲインとして

$$
\tau_{f f}=-\alpha \hat{w}(0 \leq \alpha \leq 1)
$$

とする. 式 (25) と式 (26) をラプラス変換して, $\Theta(s)$ を消去すると, 片持ちはりに入力される外乱 $d$ とWDユ ニットに対して片持ちはりを介して入力される外乱 $w$ の間の関係

$$
W(s)=\frac{J_{u} s^{2}}{\left(J+J_{u}\right) s^{2}+C s+K} D(s)-\frac{J s^{2}+C s+K}{\left(J+J_{u}\right) s^{2}+C s+K} T(s)
$$

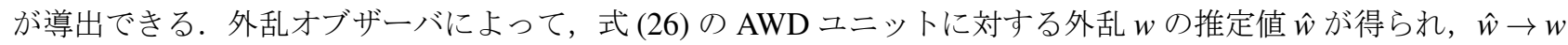
とできるものとし，外乱を相殺するために，ユニットの制御入力を $\tau=-\alpha \hat{w}$ とすると，式(41) から，外乱 $d$ から 外乱推定值 $\hat{w}$ までの伝達関数

$$
\hat{W}(s)=\frac{J_{u} s^{2}}{\left\{(1-\alpha) J+J_{u}\right\} s^{2}+(1-\alpha) C s+(1-\alpha) K} D(s)
$$

が得られる.同様に $\tau=-\alpha \hat{w}$ とすると, 式 (28)のラプラス変換と式 (42) から

$$
\Theta(s)=\frac{1}{\left\{\left(J+J_{u}\right) s^{2}+C s+K\right\}+\left(\frac{\alpha}{1-\alpha}\right) J_{u} s^{2}} D(s)
$$

が得られる. 式(43)において， $\alpha$ を 0 から大きくしていくと，外乱から $\theta$ までの伝達関数のゲインが低下してい き， $\alpha$ を 1 に近づけることで外乱に対する片持ちはりのたわみ振動の応答が 0 に近づくことが分かる.このこと は, 式 (28) の右辺が 0 となっていることに相当することから, 結果的に外乱推定值 $\hat{w}$ が片持ちはりへの外乱入力 $d$ に漸近することを表している.

これ以降，式 (30) のスカイフック制御と式 (40) の適応外乱相殺制御を併合した制御系をスカイフック・適応外 乱相殺併合制御 (SWADC : Sky-hook With Adaptive Disturbance Cancellation control) と呼ぶこととする.

\section{4. シミュレーション}

シミュレーションにより提案する除振ユニットの効果を確認する。ここでは，表 1 に示す諸元を持つ真ちゅう 製片持ちはりと, 表 2 の諸元を持つ AWDユニットを想定してパラメータを決定した. これらのパラメータは後述 の実験装置に用いた片持ちはりならびに AWD ユニットの諸元である. 有限要素法によって固有振動数ならびに固 有振動モードを計算し, 式 (9) により得られる振動モデルのパラメータを表 3 に示す. ここで減衰係数 $C$ について は，はりに小さな減衰が作用するものと仮定して設定した. SWADC の制御モデルのパラメータは外乱オブザーバ モデル (式 (36)) の慣性モーメント $J_{u}$ のみであるため, 片もちはりのたわみ角に関する慣性モーメント $J$ 考慮し

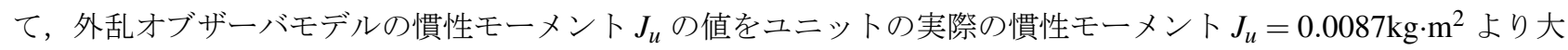
きめに設定した場合について制御系の安定性と制御性能を検討する。サンプリング周期を $10 \mathrm{~ms} し ，$ 初期条件 は $\theta=0.0, \dot{\theta}=0.0$ とした。

図 4 から図 9 は, 制御対象のモデル (式 (28)) の慣性モーメントを $J+J_{u}=0.222863+0.0087=0.23156 \mathrm{~kg} \cdot \mathrm{m}^{2}$ と し, 外乱オブザーバモデル (式 (36)) の慣性モーメント $J_{u}$ に対して, 表 4 に示すパラメータを用いた場合について, 
Table 1 Parameters of brass beam

\section{Mass}

1.78

Length

0.78

Thickness

0.0025

Width

Density

Young's modulus

First natural frequency

(Experimental)

Second natural frequency

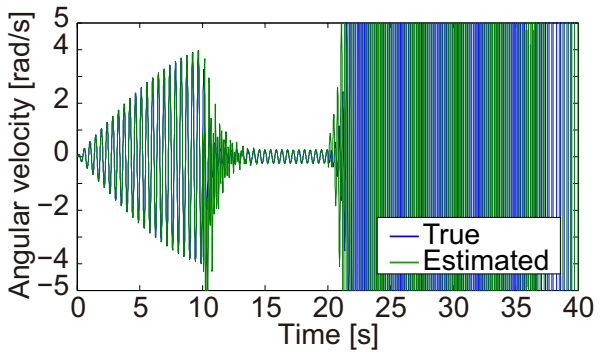

(a) Angular velocity
Table 2 Parameters of AWD unit

Moment of inertia $J_{u} \quad 0.0087 \quad \mathrm{~kg} \cdot \mathrm{m}^{2}$

Moment of inertia $J_{w} \quad 0.0106 \quad \mathrm{~kg} \cdot \mathrm{m}^{2}$

Table 3 Parameters of beam model

\begin{tabular}{lcc}
$J$ & 0.222863 & $\mathrm{~kg} \cdot \mathrm{m}^{2}$ \\
$C$ & 0.0006 & $\mathrm{~N} \cdot \mathrm{m} \cdot \mathrm{s} / \mathrm{rad}$ \\
$K$ & 43.3187 & $\mathrm{~N} \cdot \mathrm{m} / \mathrm{rad}$ \\
frequency & 2.2189 & $\mathrm{~Hz}$ \\
ping ratio & $9.655 \times 10^{-5}$ & - \\
\hline
\end{tabular}

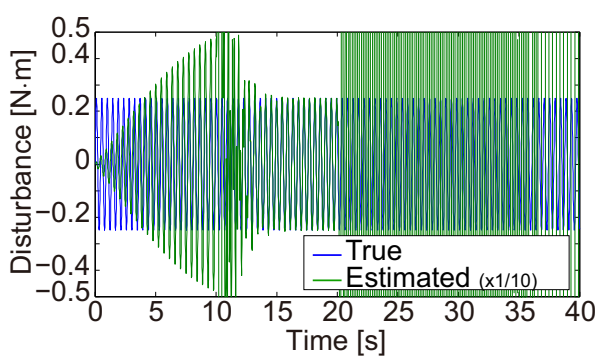

(b) Disturbance

Fig. 4 Result of simulation $\left(J_{u}=0.0087\right.$, Harmonic disturbance with $2.218 \mathrm{~Hz}, 0.25 \mathrm{~N} \cdot \mathrm{m}$, and $\left.K_{s k y}=1, \alpha=1\right)$

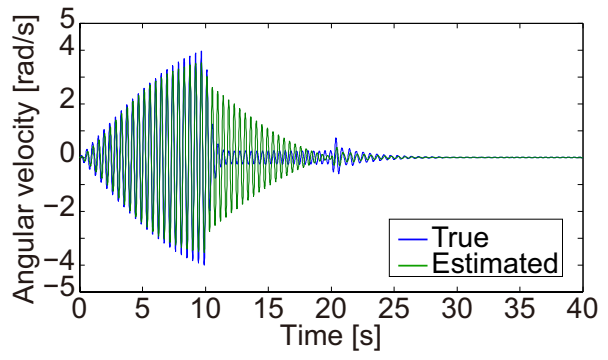

(a) Angular velocity

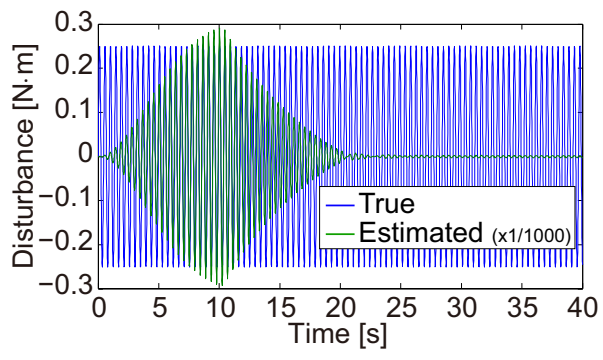

(b) Disturbance

Fig. 5 Result of simulation $\left(J_{u}=0.63\right.$, Harmonic disturbance with $2.218 \mathrm{~Hz}, 0.25 \mathrm{~N} \cdot \mathrm{m}$, and $\left.K_{s k y}=1, \alpha=1\right)$

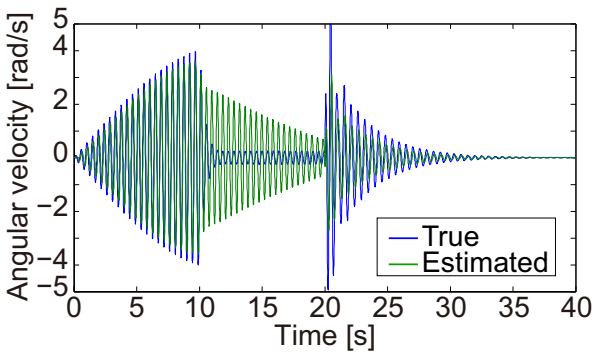

(a) Angular velocity

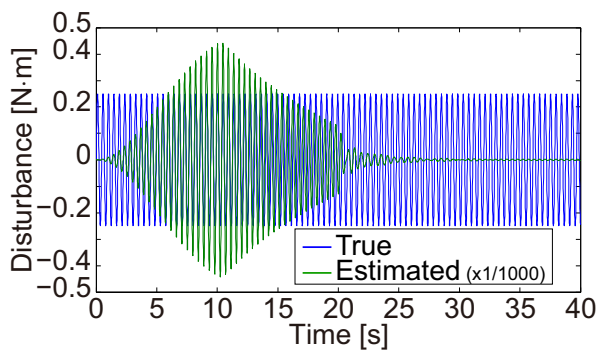

(b) Disturbance

Fig. 6 Result of simulation $\left(J_{u}=1.00\right.$, Harmonic disturbance with $2.218 \mathrm{~Hz}, 0.25 \mathrm{~N} \cdot \mathrm{m}$, and $\left.K_{s k y}=1, \alpha=1\right)$

非制御，スカイフック制御，スカイフック・外乱相殺併合制御 (SWDC，適応フィルタは用いない) を適用した場 合のシミュレーション結果である. 各図の (a) には角速度の時刻歴応答， (b) には調和励振力で与えられる外乱入 力を示し，それぞれ外乱オブザーバによる推定結果の比較を示した。ただし，(b) の外乱推定結果は凡例中に示し た縮尺で表示している.ここでは調和励振力の振動数を制御対象の固有振動数の $13.942 \mathrm{rad} / \mathrm{s}(2.218 \mathrm{~Hz})$, 振幅を $0.25 \mathrm{~N} \cdot \mathrm{m}$ とした. 図 4 から図 6 は, スカイフック制御ゲイン $K_{s k y}$ を 1 , 外乱相殺制御ゲイン $\alpha$ をとした場合の 結果であり, 図 7 から図 9 は, スカイフック制御ゲイン $K_{s k y}$ を 0.7 , 外乱相殺制御ゲイン $\alpha$ を 0.7 とた場合の 結果である. 0 秒から 10 秒まで制御入力を 0 とし，10 秒から 20 秒までの間についてはスカイフック制御による 


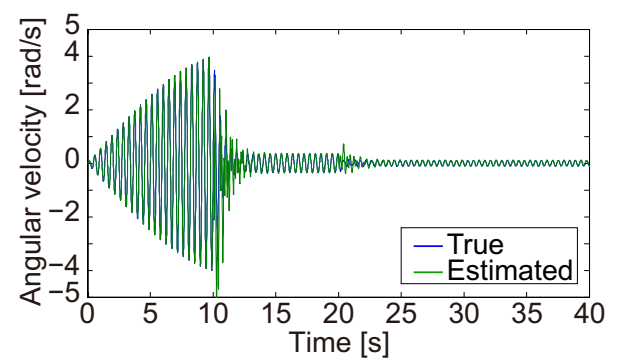

(a) Angular velocity

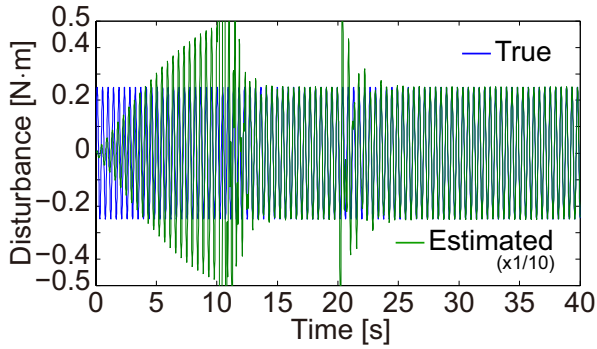

(b) Disturbance

Fig. 7 Result of simulation $\left(J_{u}=0.0087\right.$, Harmonic disturbance with $2.218 \mathrm{~Hz}, 0.25 \mathrm{~N} \cdot \mathrm{m}$, and $\left.K_{s k y}=0.7, \alpha=0.7\right)$

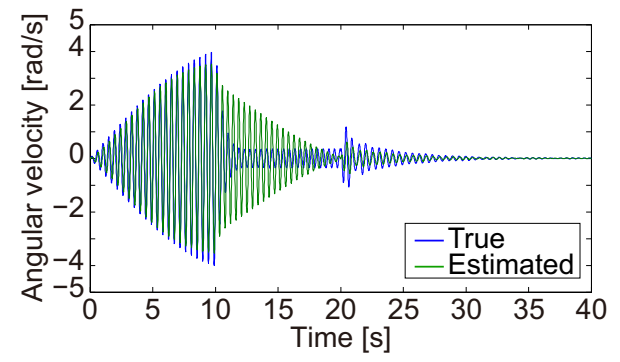

(a) Angular velocity

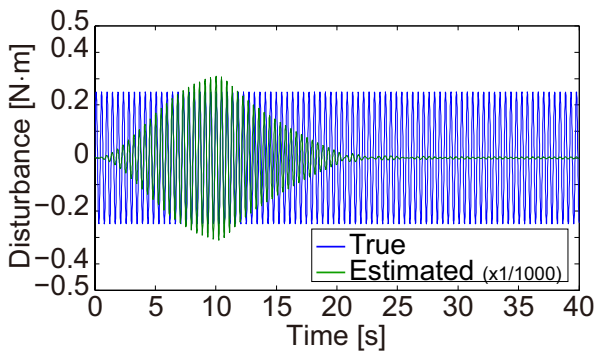

(b) Disturbance

Fig. 8 Result of simulation $\left(J_{u}=0.63\right.$, Harmonic disturbance with $2.218 \mathrm{~Hz}, 0.25 \mathrm{~N} \cdot \mathrm{m}$, and $\left.K_{\text {sky }}=0.7, \alpha=0.7\right)$

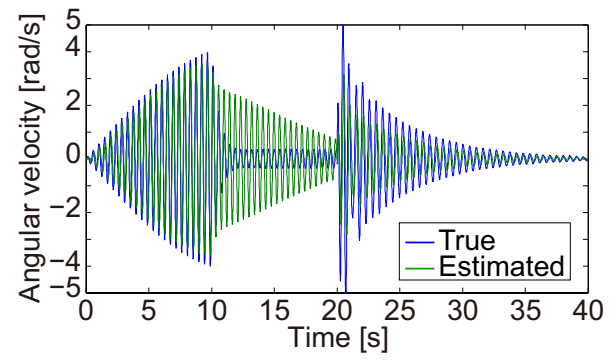

(a) Angular velocity

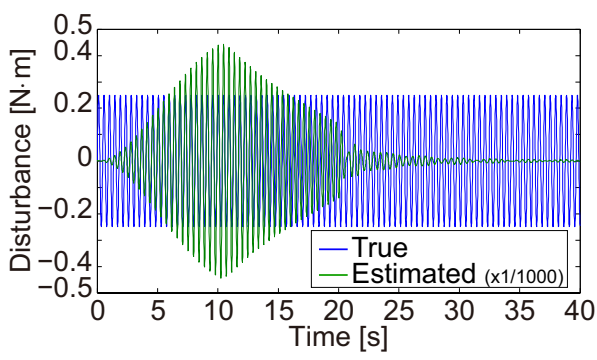

(b) Disturbance

Fig. 9 Result of simulation $\left(J_{u}=1.00\right.$, Harmonic disturbance with $2.218 \mathrm{~Hz}, 0.25 \mathrm{~N} \cdot \mathrm{m}$, and $\left.K_{\text {sky }}=0.7, \alpha=0.7\right)$

Table 4 Poles of observer model

\begin{tabular}{c|ccc}
\hline Moment of inertia $J_{u}\left[\mathrm{~kg} \cdot \mathrm{m}^{2}\right]$ & 0.0087 & 0.63 & 1.00 \\
\hline Poles & -1.664 & -9.525 & -9.525 \\
& $-4.1679 \pm 34.742 \mathrm{j}$ & $-0.2374 \pm 14.335 \mathrm{j}$ & $-0.2374 \pm 9.7081 \mathrm{j}$ \\
\hline$l_{d 1}$ & $-1.5757 \times 10^{-1}$ & $-1.0080 \times 10^{-1}$ & $-1.0050 \times 10^{-1}$ \\
$l_{d 2}$ & $-1.0018 \times 10^{-1}$ & $-1.0018 \times 10^{-1}$ & $-1.0018 \times 10^{-1}$ \\
$l_{d 3}$ & $-2.7262 \times 10^{-3}$ & $-2.7262 \times 10^{-3}$ & $-2.7262 \times 10^{-3}$ \\
\hline
\end{tabular}

Frequency of harmonic disturbance model is $2.2 \mathrm{~Hz}$. Feedback gains for observer $l_{1}, l_{2}, l_{3}$ are -10 .

フィードバック制御入力を与え， 20 秒からフィードフォワード制御による外乱相殺制御を行った.

はじめに，スカイフック制御の制振効果を確認する. 図 4 から図 9 のいずれにおいても，10 秒から 20 秒までの 間にはスカイフック制御により振動が減衰しているが，振動を完全には除去できていないことが分かる.

次に, 式 (36) の外乱オブザーバモデルの慣性モーメント $J_{u}$ を変化させた場合の制御効果への影響を確認する. 図 4 から図 9 を比較すると，オブザーバモデルの慣性モーメントを AWD ニニットの実際の慣性モーメント $J_{u}=0.0087$ $\mathrm{kg} \cdot \mathrm{m}^{2}$ とした場合 (図 4, 図 7), オブザーバの状態推定精度が良いことが分かる. しかしながら，スカイフック制 御ゲイン $K_{s k y}$, 外乱相殺制御ゲイン $\alpha$ を共に 1 として外乱相殺制御を適用した場合 (図 4), 外乱相殺制御を適用し た際に閉ループ系が不安定となっていることが分かる. 図 7 に示すようにスカイフック制御ゲイン $K_{s k y}$, 外乱相殺 制御ゲイン $\alpha$ を共に 0.7 まで下げると，制御系は安定であることが分かる．表 4 を見ると， $J_{u}=0.0087 \mathrm{~kg} \cdot \mathrm{m}^{2}$ の 場合には，式(36) を離散時間系に変換した際に $\boldsymbol{L}$ から得られるゲイン $\boldsymbol{L}_{d}=\left[\begin{array}{llll}l_{d 1} & l_{d 2} & l_{d 3}\end{array}\right]^{T}$ の角速度に関するゲイン 


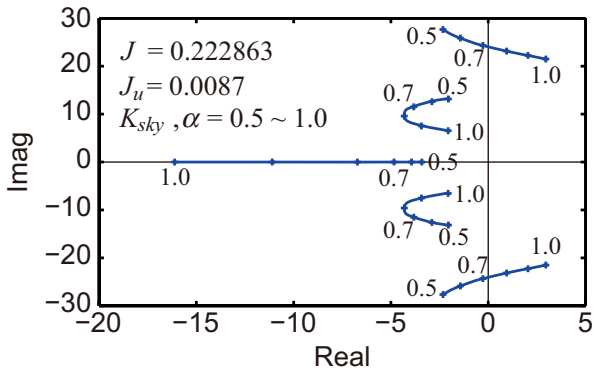

(a) $J_{u}^{*}=0.0087$

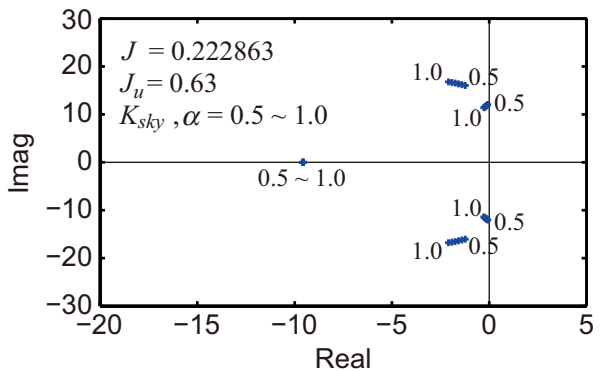

(b) $J_{u}^{*}=0.63$

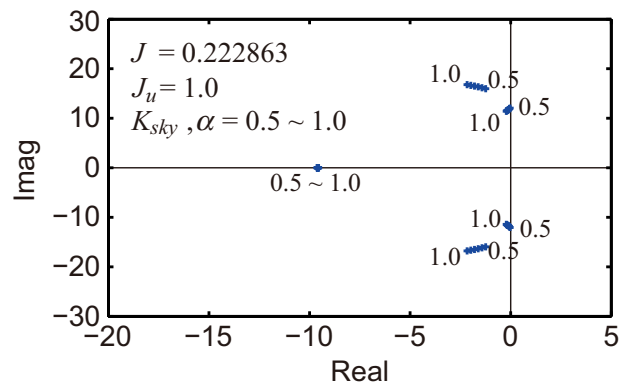

(c) $J_{u}^{*}=1.0$

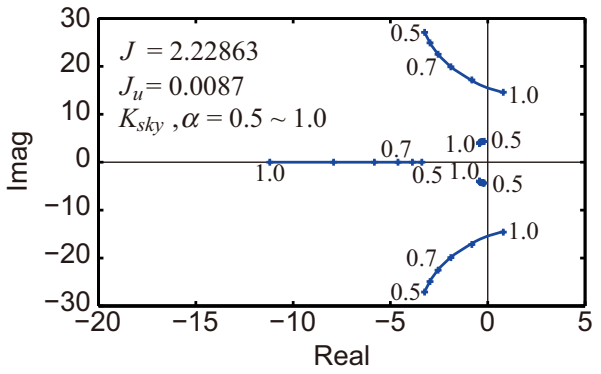

(a) $J_{u}^{*}=0.0087$

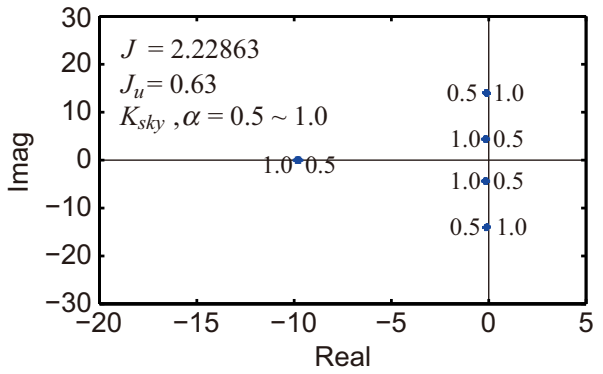

(b) $J_{u}^{*}=0.63$

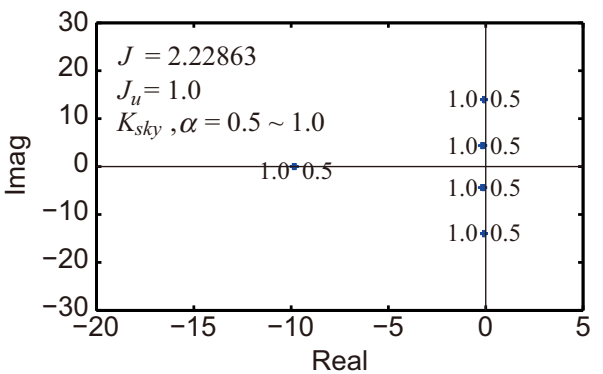

(c) $J_{u}^{*}=1.0$

Fig. 10 Root locus, $J=0.222863$, and $\left(K_{s k y}, \alpha\right)=$ Fig. 11 Root locus, $J=2.22863$, and $\left(K_{s k y}, \alpha\right)=$ $0.5 \rightarrow 1.0$

$0.5 \rightarrow 1.0$

$l_{d 1}$ が他の場合と比べて大きくなっていることが分かる. スカイフック制御入力は角速度 $\dot{\theta}$ にフィードバックゲイ ン $K_{s k y}$ を乗じたものであるため，外乱相殺制御を同時に適用した場合には，外乱オブザーバモデル (式 (36)) への 入力 $\tau$ に対して角速度 $-K_{s k y} \dot{\theta}$ が入力となり，加えてゲイン $l_{d 1}$ に $\dot{\theta}$ を乗じたフィードバックが行われる. その結 果 $\dot{\theta}$ に関するオブザーバへのフィードバックゲインが大きくなるため，フィードバック系を不安定としているもの と考えられる. $J_{u}=0.63 \mathrm{~kg} \cdot \mathrm{m}^{2}$ とした場合 (図 5, 図 8) には, 20 秒以降の外乱相殺制御時の振幅が他の場合とく らべて小さくなっており，高い除振性能が得られることが分かる．それぞれの図の (b) を見ると， $J_{u}$ を大きく設定 した場合には，推定される外乱の振幅が大きくなっていることが分かり，外乱相殺制御開始時の 20 秒の時点で一 度振幅が大きくなっている。 $J_{u}$ が大きい場合には推定される外乱が実際の外乱よりも大きくなるため, 外乱相殺 制御の入力が実際の外乱と釣り合わずに一度振動が大きくなり，その後収束したものと考えられる．Ju=0.0087 $\mathrm{kg} \cdot \mathrm{m}^{2}$ よりも大きく設定した場合 $\left(J_{u}=0.63,1.0\right)$ では，スカイフック制御ゲイン $K_{s k y}$ ならびに外乱相殺制御ゲイン $\alpha$ を 1 とした場合でも閉ループ系が安定であり，さらに外乱相殺制御の効果が高いことが分かる.

そこで, SWADC のパラメータ $K_{s k y}$ と $\alpha$ ならびに $J_{u}$ から変更した外乱オブザーバモデルの慣性モーメント $J_{u}^{*}$ を変化させた場合について, 式 (28), (29), (30), (36), (40) から得られる閉ループ系の状態方程式

$$
\left[\begin{array}{c}
\dot{\theta} \\
\ddot{\theta} \\
\hline \dot{\hat{\theta}} \\
\hline \dot{\hat{w}} \\
\ddot{\hat{w}}
\end{array}\right]=\left[\begin{array}{cc|c|cc}
0 & 1 & 0 & 0 & 0 \\
-\frac{K}{J+J_{u}} & -\frac{C+K_{\text {sky }}}{J+J_{u}} & 0 & -\frac{\alpha}{J+J_{u}} & 0 \\
\hline 0 & -\left(l_{1}+\frac{K_{s k y}}{J_{u}^{*}}\right. & l_{1} & \frac{1-\alpha}{J_{u}^{*}} & 0 \\
\hline 0 & -l_{2} & l_{2} & 0 & 1 \\
0 & -l_{3} & l_{3} & -\omega_{k}^{2} & 0
\end{array}\right]\left[\begin{array}{c}
\theta \\
\dot{\theta} \\
\dot{\hat{\hat{\theta}}} \\
\hline \hat{w} \\
\dot{\hat{w}}
\end{array}\right]+\left[\begin{array}{c}
0 \\
\frac{1}{J+J_{u}} \\
\hline 0 \\
\hline 0 \\
0
\end{array}\right] d
$$




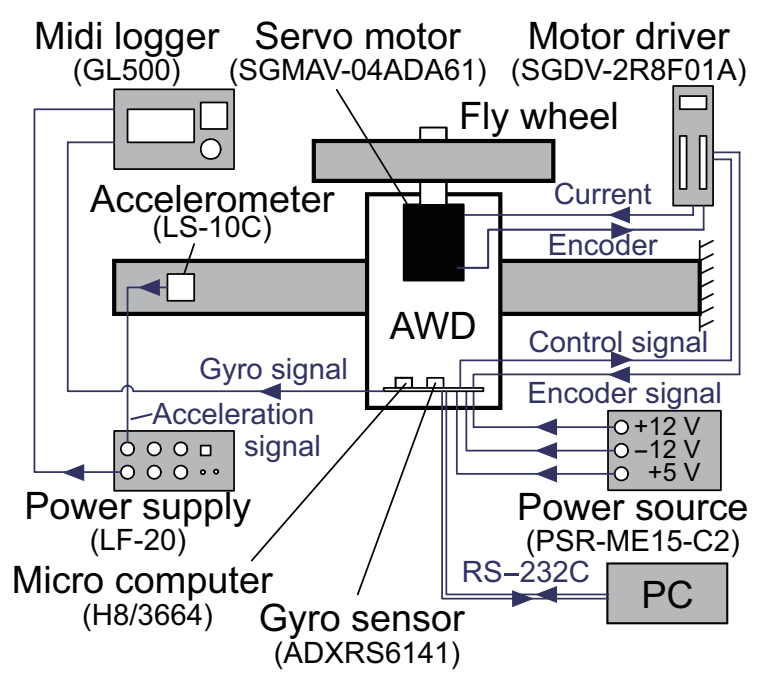

Fig. 12 Experimental setup

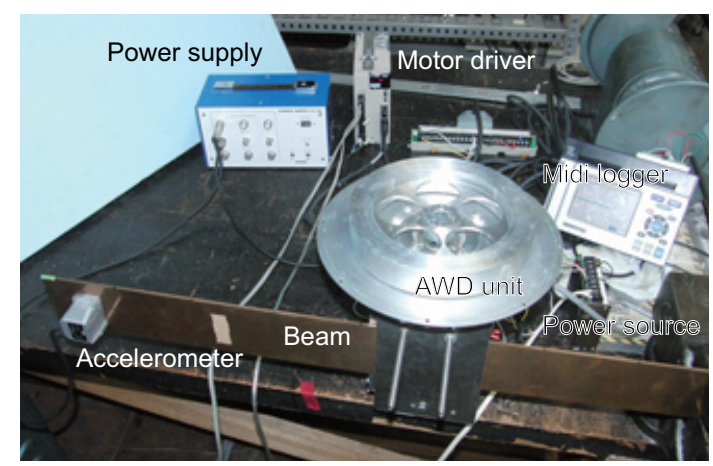

Fig. 14 Photo of the experimental setup

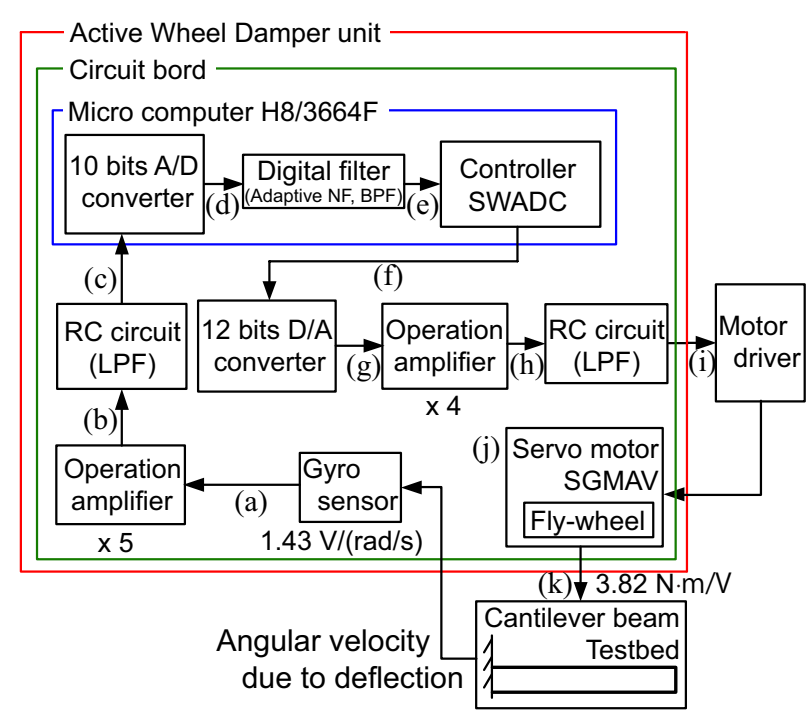

Fig. 13 Block diagram of AWD unit

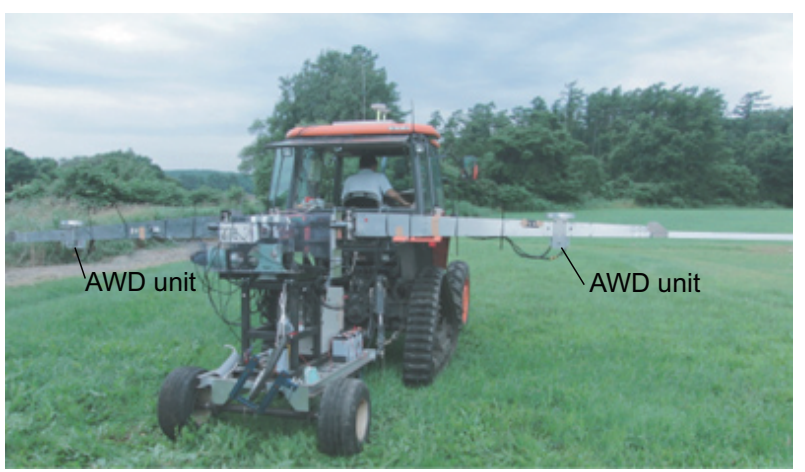

Fig. 15 Boom sprayer

の極から閉ループ系の安定性について考察を行う。図 10 と 11 は式 (44) 中のパラメータを変化させた場合の極の 変化を示す根軌跡である。図 10 は，はりモデルの慣性モーメント $J$ にシミュレーションで用いた值を用いた場合 の結果であり，図 11 は，はりモデルの慣性モーメント $J$ を 10 倍とした場合の結果である. これらの結果から外乱 オブザーバモデルの慣性モーメント $J_{u}$ を AWDユニットの慣性モーメントより大きく設定することで，スカイフッ ク制御と外乱相殺制御のパラメータに対して，極の変化が小さくなることが分かる (図 10 と図 11 の (b)(c)). 外乱 オブザーバモデルの慣性モーメントを 0.0087 とした場合の図 10 と図 11 の (a)から， $K_{s k y}$ と $\alpha$ を とした場合に は右半平面内に極が存在し，閉ループ系が不安定となっていることが分かる．また， $J_{u}^{*}=0.0087$ とた場合でも， $K_{s k y}$ と $\alpha$ を 0.7 程度とすることで, 極が左半平面内に配置され, 閉ループ系が安定となることが分かる. 従って, 外乱オブザーバモデルの慣性モーメント $J_{u}$ を大きめに設定し，さらに $K_{s k y}$ と $\alpha$ を 0.7 程度とすることで，広いパ ラメータ範囲の制御対象に対して，制御系の安定性を確保できることが解析的にも確認できる.

\section{5. 自由 振 動 試 験}

実験装置の構成を図 12 ならびに図 13 に示す。ここでは, 自由振動時における制振ユニットの制振性能の検証 を行う。制御対象は表 1 の諸元をもつ $0.78 \mathrm{~m}$ の真ちゅう製片持ちはり(図 14)である. AWDユニットにはサーボ モータ (SGMAV-04ADA61, 安川電機) を搭載し, モータドライバとしてサーボパック (SGDV-2R8F01A, 安川電 機) を用いた. 最終的に図 15 に示すような $4 \mathrm{~m}$ の柔軟片持ちはり状ブームを有する農薬散布用ブームスプレーヤ

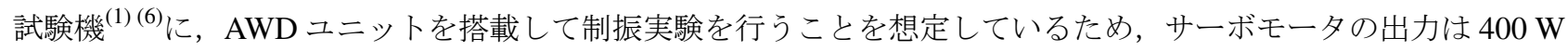
としている. 電圧の計測にはデータロガー (midi LOGGER GL500，グラフテック) を用い，マイコンプログラム上 の変数についてはマイコン (H8/3664, ルネサスエレクトロニクス) に搭載された RS-232C ポートによるシリアル通 


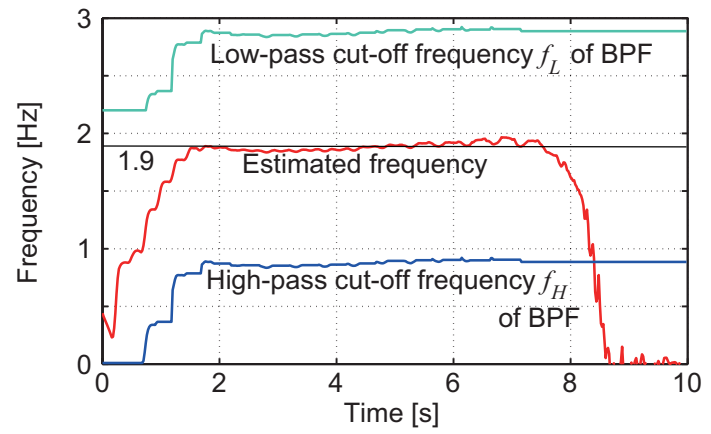

Fig. 16 Estimated frequency

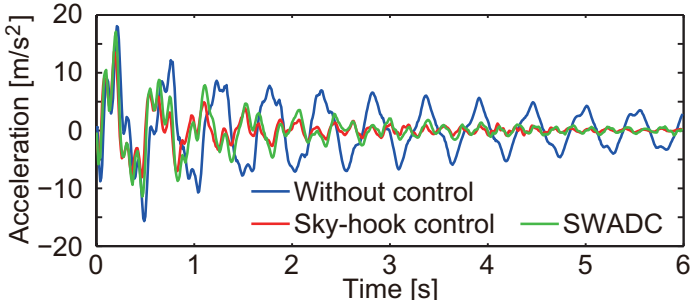

Fig. 17 Experimental results of acceleration

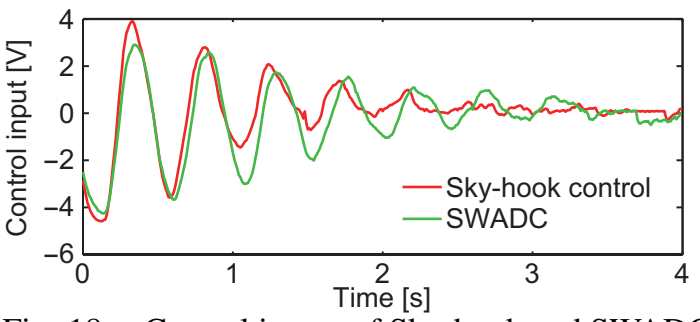

Fig. 18 Control inputs of Sky-hook and SWADC

信で取得した。ジャイロセンサ (ADXRS6141，Analog Devices)の感度は $25 \mathrm{mV} /(\mathrm{deg} / \mathrm{s})$ である. 制御性能の確認 のために，加速度ピックアップ (LS-10C，リオン) をはりに取り付け，センサアンプ (LF-20，リオン)により増幅 した加速度信号を計測した。

片持ちはりの先端に $10 \mathrm{~cm}$ の初期変位を与えて初期值応答を比較した。ここではマイコンからのシリアル通信で 得られる適応ノッチフィルタのノッチ角周波数 $\omega_{k}$ や, バンドパスフィルタ (BPF) のハイパス, ローパスフィルタ の折点周波数 $f_{H}, f_{L}$, 増幅回路から得られる角速度 (図 13(c)) と制御入力 (図 13(i)), はりに取り付けた加速度セ ンサから得られる加速度を計測した (図 12). 適応フィルタを用いた制御系をマイコン上にアセンブラならびにC 言語で実装した，スカイフック制御に適用するバンドパスフィルタの定数は $f_{H}=0.3 \mathrm{~Hz}, f_{L}=2.3 \mathrm{~Hz}$ とした. 適 応フィルタを組み込んだ外乱相殺制御 (SWADC) ではオンラインで適応ノッチフィルタの振動数推定值を取得し, 適応 BPF の折点周波数 $f_{H}, f_{L}$ ならびに外乱オブザーバの外乱モデルの円振動数 $\omega_{k}$ を逐次更新していく.まず, はりの固有振動数を推定するために適応ノッチフィルタによる振動数推定を行う. 適応ノッチフィルタの定数は 予備実験の結果から $\rho_{\mathrm{NF}}=0.97, \lambda=0.97$ とした。適応ノッチフィルタの推定值を基に適応バンドパスフィルタ の定数を逐次更新する. バンドパスフィルタの定数は適応ノッチフィルタの推定值が $1.2 \mathrm{~Hz}$ を超えたときに更新 し， $1.2 \mathrm{~Hz}$ に達していないときは $f_{H}=0.1 \mathrm{~Hz}, f_{L}=2.2 \mathrm{~Hz}$ に設定している. また，ジャイロセンサの出力振幅が 小さいときは適応ノッチフィルタの推定精度が悪いため，一定振幅以下になったときにバンドパスフィルタの定 数の更新を停止している. 図 16 に結果を示す. 適応ノッチフィルタの推定が開始される約 0.7 秒まで，バンドパ スフィルタの定数は $f_{H}=0.1 \mathrm{~Hz}, f_{L}=2.2 \mathrm{~Hz}$ となっており, $\omega_{k}$ の推定中は, $f_{k}=\omega_{k} /(2 \pi)$ として $f_{H}=\left(f_{k}-1\right)$ $\mathrm{Hz}, f_{L}=\left(f_{k}+1\right) \mathrm{Hz}$ に設定されている. また，ジャイロセンサの出力信号が小さいとき (約 7 秒以降) は推定值が $0 \mathrm{~Hz}$ 付近に落ちてしまっているが，バンドパスフィルタの定数はその前に更新を止めて適切な帯域を保っている. また，AWDユニット搭載後のはりの振動数が約 $1.9 \mathrm{~Hz}$ であることが分かる. 表 1 の実験による AWDユニット 搭載前の振動数 $2.05 \mathrm{~Hz}$ と比べて, AWD ユニットの質量が付加されたことにより振動数がわずかに低下したもの と考えられる。この結果から $1.9 \mathrm{~Hz}$ をスカイフック制御のバンドパスフィルタの中心周波数とした。ささに，制 御系とオブザーバのパラメータについてはシミュレーション結果から, 最も性能が良いと思われる図 5 と同じく $J_{u}=0.63, l_{1}=-10, l_{2}=-10, l_{3}=-10, K_{s k y}=1, \alpha=1$ とした. 図 17 は非制御，スカイフック制御，スカイ フック・適応外乱相殺併合制御 (SWADC) を適用した場合の，加速度センサで取得したはり先端の加速度の時刻歴 応答である。非制御時と比較してスカイフック制御とSWADC を適用した場合は振動の減衰が早く，高い制振効 果が得られていることが分かる。この実験では，スカイフック制御，SWADCについては大きな違いは見られな い. SWADC は調和外乱を相殺する制御系であるため，初期值応答に関してはスカイフック制御と同等の制御効 果が得られているものと考えられる。なお，連続的な外乱が作用する場合については，牽引される台車に柔軟は り構造物を搭載して走行する実験を行い，AWD ユニットによる SWADC の除振性能が最も高いことを確認した (6). 図 18 はスカイフック制御と SWADC の制御時の制御入力の時刻歴応答である.ここではスカイフック制御と 
SWADC の制御入力を比較するため，制御入力が行われている4 秒までの結果を示した. SWADCの制御入力の振 幅が 1 秒以降大きいのが分かる。この理由は，この実験が定常外乱に対する応答ではなく初期值応答によるもの であり，外乱相殺制御入力がスカイフック制御入力に加わることで大きくなっているものと考えられる.

\section{6. ま と め}

本研究では, 片持ちはりの柔軟変形に伴う振動の抑制のために，はり等の柔軟構造物に簡単に搭載できる回転 マスダンパ型アクティブ制振ユニットを開発し，フィードバック制御としてスカイフック制御，フィードフォワー ド制御として外乱相殺制御系を併合した，スカイフック・適応外乱相殺制御を構成し，制御性能の向上を図った。 ここでは，適応ノッチフィルタアルゴリズムを応用してリアルタイムに振動の振動数を推定し，調和外乱才ブザー バの振動数を適応的に更新することで適応制御系を構築した。片持ちはりへの搭載を想定したシミュレーション を行い，オブザーバモデルのパラメータと制御ゲインが制御性能に与える影響を確認し，実験により制振性能を 確認した。その結果，適切な制御パラメータを用いることで，スカイフック・適応外乱相殺制御によって，高い 制振性能が得られることが分かった。

\section{謝辞}

本研究は北海道重点領域特別研究（大規模農業に向けた走行安定化機能を搭載した高速農作業機械の開発）の 支援を受けた研究であり，ここに感謝の意を表します.

\section{文献}

（1）梅田遼平, 星野洋平, 小林幸徳, 江丸貴紀, 中西洋介, “適応アクティブ制振ユニットの開発とブームスプレーヤヘの適 用”, 第 42 回計測自動制御学会北海道支部学術講演会論文誌 (2010), pp.27-30.

（2）小林正樹, 赤川智宏, 伊藤良生, “全域通過フィルタを用いた適応ノッチフィルタのアルゴリズムと収束性”, 電子情報通 信学会論文誌 (A), J82, 3 (1999), pp.325-332.

(3) Oh, C.S., Bang, H.C. and Park, C.S., "Attitude Control of a Flexible Launch Vehicle Using an Adaptive Notch Filter (Ground Experiment)", Control Engineering Practice, 16 (2008), pp.30-42.

（4）野波健蔵, “調和励振力を受ける多自由度振動系の外乱相殺制御”, 日本機械学会論文集 C 編, Vol. 57, No. 534 (1991), pp.22-28.

(5) 廣野好之, 小林幸徳, 山田元, “渦励振される弾性支持円柱の外乱相殺制御”, 日本機械学会論文集 C 編, Vol. 68, No. 669 (2002), pp.55-62.

（6）星野洋平，片山恭平，小林幸徳，中西洋介，江丸貴紀，“スカイフックー適応外乱相殺併合制振制御ユニットによるスプレー ヤブームのアクティブ振動抑制”, 第 12 回運動と振動の制御シンポジウム MOVIC2011 講演論文集 (2011), pp.409-414. 